\title{
max \\ Using Wood-Based Waste from Grapevine Cultivation for Energy Purposes
}

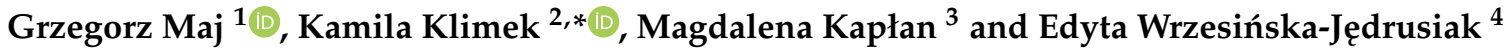 \\ 1 Department of Power Engineering and Transportation, University of Life Sciences in Lublin, Głęboka 28, \\ 20-612 Lublin, Poland; grzegorz.maj@up.lublin.pl \\ 2 Department of Applied Mathematics and Computer Science, University of Life Sciences in Lublin, Głęboka 28, \\ 20-612 Lublin, Poland \\ 3 Institute of Horticulture Production, University of Life Sciences in Lublin, Głęboka 28, 20-612 Lublin, Poland; \\ magdalena.kaplan@up.lublin.pl \\ 4 Department of Renewable Energy Sources Falenty, Institute of Technology and Life Sciences, Al. Hrabska 3, \\ 05-090 Raszyn, Poland; e.jedrusiak@itp.edu.pl \\ * Correspondence: kamila.klimek@up.lublin.pl; Tel.: +48-81-531-96-30
}

\section{check for} updates

Citation: Maj, G.; Klimek, K.; Kapłan, M.; Wrzesińska-Jędrusiak, E. Using Wood-Based Waste from Grapevine Cultivation for Energy Purposes. Energies 2022, 15, 890. https:// doi.org/10.3390/en15030890

Academic Editors: Elena Rada, Marco Ragazzi, Ioannis Katsoyiannis, Elena Magaril, Paolo Viotti, Hussain H. Al-Kayiem, Marco Schiavon, Gabriela Ionescu and Natalia Sliusar

Received: 5 January 2022

Accepted: 24 January 2022

Published: 26 January 2022

Publisher's Note: MDPI stays neutral with regard to jurisdictional claims in published maps and institutional affiliations.

Copyright: (C) 2022 by the authors. Licensee MDPI, Basel, Switzerland. This article is an open access article distributed under the terms and conditions of the Creative Commons Attribution (CC BY) license (https:// creativecommons.org/licenses/by/ $4.0 /)$.

\begin{abstract}
This paper presents the possibility of the energetic utilization of biowaste in the form of lignified one-year shoots from the cultivation of grapevines of the Seyval Blanc (WSBL), Solaris (WSOL), Regent (WREG) and Rondo (WRON) varieties, grown in temperate climate zones. A technical analysis, an elemental analysis and the determination of the highest heat value and lowest heat value were performed to define the quality parameters of waste as fuel. In addition, the emission factors of $\mathrm{SO}_{2}, \mathrm{NO}_{x}, \mathrm{CO}, \mathrm{CO}_{2}$ and dust were estimated to demonstrate the impact of potential biowaste from combustion. Based on the stoichiometric equations, the exhaust gas composition, the theoretical oxygen demand and the total flue gas volume were evaluated. The study showed that the material with the highest energy potential was WREG (LHV-16.19 MJ $\cdot \mathrm{kg}^{-1}$ ), with an ash content of $3.68 \%$, while the lowest potential was found for WRON (LHV-15.88 MJ. $\mathrm{kg}^{-1}$ ), with an ash content of $4.21 \%$. The study showed that the use of the studied viticulture waste instead of hard coal could reduce $\mathrm{CO}$ emissions by $26-27 \%, \mathrm{CO}_{2}$ by $24-26 \%, \mathrm{NO}_{\mathrm{x}}$ by $55-56 \%, \mathrm{SO}_{2}$ by $96-97 \%$ and dust by $77-80 \%$
\end{abstract}

Keywords: grapevine shoots; biowaste managment; energy properties; LHV; emission factors

\section{Introduction}

Grapevine is a species of great economic importance and is very widespread globally, its cultivated area in 2018 amounted to 7.4 million ha [1]. In Poland, grapevine is of little economic importance; nevertheless, the grapes and wines produced there are of very good quality [2-6]. In the 2020/2021 marketing year, producers registered with the National Support Centre for Agriculture (KOWR) cultivated grapevines on 547.39 ha [7]. The high interest in grapevine cultivation in temperate climates is due, among other things, to the introduction into cultivation of new interspecies hybrids of grapevines, which, due to their high resistance to fungal diseases, are quite popular, especially in organic vineyards. Botanical species of Vitis vinifera L. include PIWI varieties (from the German "pilzwiderstandsfähige rebsorten" - vine varieties resistant to fungal diseases) often cultivated in Northern European countries [8,9]. For example, Hibernal, Regent, and Solaris varieties are grown in Germany, while Malverina, Savilon, and Laurot are grown in the Czech Republic [9]. According to Sinoquet [10], the 10 most prevalent PIWI group varieties grown in Switzerland in the 2015/2016 season included: Muscat Bleu, Cabernet Jura, Solaris, Johanniter, Leon Millot, Maréchal Foch, Regent, Seyval Blanc, Souvignier Gris, and Divico. The use of hybrids is also widespread in regions outside Europe. In South America, hybrids and V. labrusca are used to produce sparkling wines. [11]. In Brazil 
(Rio Grande do Sul), most vineyards are based on American varieties and hybrids, while European varieties, such as Cabernet Cortis, Cabernet Carbon, Bronner, and Regent, make up only $7 \%$ [12].

Grapevines, unlike other orchard species, require intensive pruning to obtain adequate production volume and quality [13]. The recovery of plant biomass in the form of grapevine pruning residues and wastes and the possibility of their use for energy purposes represents one of the most important innovations in the agricultural sector [14-19]. Agricultural residues can become a potential source of biomass for energy production because they are available annually [20,21]. Total wood production in a given year depends on a number of factors, i.e., variety, rootstock, habitat conditions, fertilization, health, and planting density [22].

Grapevine pruning residues should be removed before any other maintenance is undertaken $[16,17,19,23,24]$. In commodity vineyards, they are mulched on site or stored outside the vineyard and burned $[17,25]$. However, these solutions are problematic in terms of economy, environment and time consumption. Mulching contributes to the maintenance of organic matter, nutrients, and soil moisture, but it is also very dangerous in terms of disease spread [26]. Burning, besides being labor intensive, is cheap [27], but is characterized by the emission of significant amounts of particulate matter into the atmosphere [28]. Of particular note is the fact that grapevine pruning residues have particular quality characteristics compared to other lignocellulosic raw materials, which may influence the choice and efficiency of conversion technologies [29], as well as the potential for co-combustion [30].

A study by Corona and Nicoletti [31] presented data indicating that in Agrigento County, Italy, biomass production, which includes pruned shoots, is $2.69 \mathrm{t} \cdot \mathrm{ha}^{-1}$ per year. The research presented in this paper is innovative because the evaluation of 'PIWI' varieties for biomass residues and potential for energy use is little known compared to varieties commonly grown globally, which belong to the Vitis vinifera species $[17,25,27,29]$.

This study aimed to evaluate the energy and emission usefulness of one-year waste shoots of four grapevine varieties, i.e., Seyval Blanc, Solaris, Regent, Rondo, grown in a temperate climate zone.

\section{Materials and Methods}

The experimental material consisted of one-year-old woody shoots, so-called phloem, taken in spring 2020 from four grapevine varieties, Seyval Blanc (WSBL), Solaris (WSOL), Regent (WREG) and Rondo (WRON), commonly grown in Poland. The Nobilis vineyard $\left(50^{\circ} 39^{\prime} \mathrm{N} ; 21^{\circ} 34^{\prime} \mathrm{E}\right)$ is located in the Sandomierska Upland in the south-eastern part of the country. Self-rooted grapevines of the studied varieties were planted in spring 2010 at a distance of $2.0 \mathrm{~m} \times 1.0 \mathrm{~m}\left(5000\right.$ plants $\left.\cdot \mathrm{ha}^{-1}\right)$ on loess soil. Plants were managed as a single fixed twine with a trunk height of $40 \mathrm{~cm}$ and one fixed arm length of about $0.9 \mathrm{~m}$, on which 6 pivots were left each year after application of short pruning, from which 12 to 16 fruiting shoots, the so-called vines, were derived.

The experiment was set up in a randomized block design and included four combinations with five repetitions. The repetitions were plots in which 10 plants were growing. On shrubs included in the experiment, shoots before pruning were counted (N; pcs.), then their diameter at the base $(\mathrm{D} ; \mathrm{mm})$ was measured using a caliper with an accuracy of $0.01 \mathrm{~mm}$. After cutting, shoots from all plants included in the experiment were weighed on a precision balance PS R2 RADWAG with an accuracy of $0.001 \mathrm{~kg}$ and referred to the scale of a shrub (Msh; $\mathrm{kg} \cdot \mathrm{shrub}^{-1}$ ) and a crop area (Mha; $\left.\mathrm{t} \cdot \mathrm{ha}^{-1}\right)$. Fifty representative shoots were selected for further processing from each grapevine variety evaluated.

The material was ground to a particle size of $0.5 \mathrm{~mm}$ with a Retsch SM 100 grinder for each analysis. All the determinations were carried out (ultimate and proximate) in the work with triple repetition (Table 1). 
Table 1. Determinations carried out in the study.

\begin{tabular}{|c|c|c|}
\hline Parameter & Equipment & Standard \\
\hline $\operatorname{Ash}(\mathrm{A} ; \%)$ & & EN-ISO 18122 \\
\hline Volatile matter $(\mathrm{V} ; \%)$ & LECO TGA 701 & EN-ISO 18123 \\
\hline Moisture (M; \%) & & EN-ISO 18134-3 \\
\hline $\begin{array}{c}\left.\text { Higher heat value (HHV; MJ. } \mathrm{kg}^{-1}\right) \\
\left.\text { Lower heat value (LHV; MJ } \cdot \mathrm{kg}^{-1}\right)\end{array}$ & LECO AC 600 & EN-ISO 1928:2009 \\
\hline $\begin{array}{c}\text { Fixed carbon }(\mathrm{FC} ; \%)[14] \\
\text { Carbon }(\mathrm{C} ; \%)\end{array}$ & - & $\mathrm{FC}=100-\mathrm{V}-\mathrm{A}-\mathrm{M}$ \\
\hline $\begin{array}{l}\text { Hydrogen }(\mathrm{H} ; \%) \\
\text { Nitrogen }(\mathrm{N} ; \%)\end{array}$ & LECO CHNS 628 & EN-ISO 16948:2015-07 \\
\hline Sulfur $(S ; \%)$ & & EN-ISO 16994:2016-10 \\
\hline Oxygen $(\mathrm{O} ; \%)$ [32] & - & $\mathrm{O}=100-\mathrm{A}-\mathrm{H}-\mathrm{C}-\mathrm{S}-\mathrm{N}$ \\
\hline
\end{tabular}

In order to estimate the $\mathrm{SO}_{2}, \mathrm{CO}_{2}, \mathrm{CO}, \mathrm{NO}_{\mathrm{x}}$ and dust emission indexes for the grape shoots, the index emission method was used based on the ultimate analysis; for the conversion of the indicators into an energy unit, the lower heat value (LHV) [33,34].

The exhaust gas composition was determined based on stoichiometric equations according to the works by $[35,36]$. The theoretical oxygen demand $\left(\mathrm{V}_{\mathrm{O} 2} ; \mathrm{Nm}^{3} \mathrm{O}_{2} \cdot \mathrm{kg}^{-1}\right.$ fuel $)$ was determined from the relationship:

$$
\mathrm{V}_{\mathrm{O} 2}=\frac{22.41}{100}\left(\frac{\mathrm{C}}{12}+\frac{\mathrm{H}}{4}+\frac{\mathrm{S}-\mathrm{O}}{32}\right)
$$

where: C-carbon (\%), H-hydrogen (\%), S-sulfur (\%), O-oxygen.

Since the oxygen content in the air is $21 \%$, which participates in the combustion process in the boiler, the stoichiometric volume of dry air required to burn $1 \mathrm{~kg}$ of biomass $\left(\mathrm{V}_{\mathrm{oa}}\right.$; $\mathrm{Nm}^{3}$ air $\cdot \mathrm{kg}^{-1}$ fuel) was calculated from the relationship:

$$
\mathrm{V}_{\mathrm{oa}}=\frac{\mathrm{V}_{\mathrm{O}_{2}}}{0.21}
$$

The carbon dioxide content of the combustion products $\left(\mathrm{V}_{\mathrm{CO} 2} ; \mathrm{Nm}^{3} \mathrm{CO}_{2} \cdot \mathrm{kg}^{-1}\right.$ fuel $)$ was calculated from the formula:

$$
\mathrm{V}_{\mathrm{CO}_{2}}=\frac{22.41}{12} \cdot \frac{\mathrm{C}}{100}
$$

The content of sulfur dioxide $\left(\mathrm{V}_{\mathrm{SO} 2} ; \mathrm{Nm}^{3} \mathrm{SO}_{2} \cdot \mathrm{kg}^{-1}\right.$ fuel) in the exhaust gas was determined using the formula:

$$
\mathrm{V}_{\mathrm{SO}_{2}}=\frac{22.41}{32} \cdot \frac{\mathrm{S}}{100}
$$

The water vapor content of the exhaust gas $\left(\mathrm{V}_{\mathrm{H} 2 \mathrm{O}} ; \mathrm{Nm}^{3} \mathrm{H}_{2} \mathrm{O} \cdot \mathrm{kg}^{-1}\right.$ fuel $)(7)$ is the component of water vapor volume from the hydrogen combustion process $\left(\mathrm{V}_{\mathrm{H}_{2} \mathrm{O}}^{\mathrm{H}} ; \mathrm{Nm}^{3} \mathrm{H}_{2} \mathrm{O} \cdot \mathrm{kg}^{-1}\right.$ fuel $)$ (5) and the volume of moisture contained in the combustion air $\left(\mathrm{V}_{\mathrm{H}_{2} \mathrm{O}}^{\mathrm{a}} ; \mathrm{Nm}^{3} \mathrm{H}_{2} \mathrm{O} \cdot \mathrm{kg}^{-1}\right.$ fuel $)$ (6):

$$
\begin{gathered}
\mathrm{V}_{\mathrm{H}_{2} \mathrm{O}}^{\mathrm{H}}=\frac{22.41}{100}\left(\frac{\mathrm{H}}{2}+\frac{\mathrm{M}}{18}\right) \\
\mathrm{V}_{\mathrm{H}_{2} \mathrm{O}}^{\mathrm{a}}=1.61 \cdot \mathrm{x} \cdot \mathrm{V}_{\mathrm{oa}} \\
\mathrm{V}_{\mathrm{H}_{2} \mathrm{O}}=\mathrm{V}_{\mathrm{H}_{2} \mathrm{O}}^{\mathrm{H}}+\mathrm{V}_{\mathrm{H}_{2} \mathrm{O}}^{\mathrm{a}}
\end{gathered}
$$

where: M-fuel moisture content (\%), x-air absolute humidity $\left(\mathrm{kg} \mathrm{H}_{2} \mathrm{O} \cdot \mathrm{kg}^{-1}\right.$ dry air)

The calculations took into account the most commonly accepted value of this parameter, i.e., $\mathrm{x}=10 \mathrm{~g} \mathrm{H}_{2} \mathrm{O} \cdot \mathrm{kg}^{-1}$, which, based on the Moliere diagram, corresponds to an air temperature of $25^{\circ} \mathrm{C}$ and a relative humidity of $50 \%$. 
Whereas nitrogen in the exhaust gas depends on the combustion air and solid biofuel composition, and the nitrogen content in the air is $79 \%$, the theoretical nitrogen content in the exhaust gas $\left(\mathrm{V}_{\mathrm{N}_{2}} ; \mathrm{Nm}^{3} \mathrm{~N}_{2} \cdot \mathrm{kg}^{-1}\right.$ fuel $)$ was calculated from the relationship:

$$
\mathrm{V}_{\mathrm{N}_{2}}=\frac{22.41}{28} \cdot \frac{\mathrm{N}}{100}+0.79 \cdot \mathrm{V}
$$

The total stoichiometric volume of dry exhaust gas $\left(\mathrm{V}_{\mathrm{gu}} ; \mathrm{Nm}^{3} \mathrm{dry}\right.$ flu gas $\cdot \mathrm{kg}^{-1}$ fuel $)$ was determined by the formula:

$$
\mathrm{V}_{\mathrm{gu}}=\mathrm{V}_{\mathrm{CO}_{2}}+\mathrm{V}_{\mathrm{SO}_{2}}+\mathrm{V}_{\mathrm{N}_{2}}
$$

Assuming that biomass combustion is carried out under stoichiometric conditions, with the minimum amount of air needed for combustion $(\lambda=1)$, a minimum exhaust gas volume will be obtained. The total volume of exhaust gases $\left(\mathrm{V}_{\mathrm{ga}} ; \mathrm{Nm}^{3} \mathrm{flu}\right.$ gas $\left.\cdot \mathrm{kg}^{-1} \mathrm{fuel}\right)$ was calculated according to the formula:

$$
\mathrm{V}_{\mathrm{ga}}=\mathrm{V}_{\mathrm{gu}}+\mathrm{V}_{\mathrm{H}_{2} \mathrm{O}}
$$

All statistical analyses were performed using SAS Enterprise Guide 5.1. In order to verify the correctness of the results, a preliminary analysis of the normal distribution was performed using the Shapiro-Wilk test. The significant effect of lignified shoots of four grapevines on dry biomass was verified by Tukey's test and one-way ANOVA. Multidimensional techniques were used to graphically present the examined biomass, i.e., principal component analysis or cluster analysis.

\section{Results and Discussion}

The grapevine varieties analyzed are characterized by generating large amounts of wood-based waste each year. The grape shoots obtained as a result of pruning are characterized by both a large number of woody shoots per shrub and mass (Table 2). On a per-hectare basis, a waste is obtained that needs to be managed and the quantities indicate a high potential for the utilization of raw material.

Table 2. Evaluation of lignified shoots of grapevines of Seyval Blanc-WSBL, Solaris-WSOL, RegentWREG and Rondo-WRON varieties constituting potential dry biomass.

\begin{tabular}{ccccccc}
\hline Parameter & Unit & WSBL & WSOL & WREG & WRON & $p$-Value \\
\hline $\mathrm{N}$ & pcs. & $12.0^{\mathrm{b}}$ & $14.0^{\mathrm{ab}}$ & $16.0^{\mathrm{a}}$ & $14.0^{\mathrm{ab}}$ & $0.004^{*}$ \\
$\pm \mathrm{S}_{\mathrm{d}}$ & & \pm 1.0 & \pm 1.0 & \pm 1.0 & \pm 2.0 & \\
$\mathrm{Msh}$ & $\mathrm{kg} \cdot \mathrm{shrub}^{-1}$ & $0.72^{\mathrm{b}}$ & $0.67^{\mathrm{b}}$ & $0.67^{\mathrm{b}}$ & $0.93^{\mathrm{a}}$ & $0.006^{*}$ \\
$\pm \mathrm{S}_{\mathrm{d}}$ & & \pm 0.07 & \pm 0.02 & \pm 0.02 & \pm 0.24 & \\
$\mathrm{Mha}$ & $\mathrm{t} \cdot \mathrm{ha}^{-1}$ & $3.61^{\mathrm{b}}$ & $3.38^{\mathrm{b}}$ & $3.36^{\mathrm{b}}$ & $4.65^{\mathrm{a}}$ & $0.006^{*}$ \\
$\pm \mathrm{S}_{\mathrm{d}}$ & & \pm 0.08 & \pm 1.19 & \pm 0.34 & \pm 0.11 & \\
$\mathrm{D}$ & $\mathrm{mm}$ & $8.72^{\mathrm{a}}$ & $8.01^{\mathrm{b}}$ & $8.13^{\mathrm{b}}$ & $8.24^{\mathrm{ab}}$ & $0.010^{*}$ \\
$\pm \mathrm{S}_{\mathrm{d}}$ & & \pm 0.45 & \pm 0.06 & \pm 0.16 & \pm 0.49 & \\
\hline
\end{tabular}

* Significant difference, $\mathrm{S}_{\mathrm{d}}$ - standard deviation, $\mathrm{a}, \mathrm{b}, \mathrm{ab}$ - means with the same letter in row show no significant difference at $\alpha=0.05, \mathrm{~N}-$ number of lignified shoots on the bush, Msh-Mass of lignified shoots per shrub, Mha-Mass of lignified shoots per hectare, D—Lignified shoot diameter at the base.

The number of lignified shoots per shrub ranged from 12.0 to 16.0 and differed significantly among the varieties evaluated. Significantly, the highest number of shoots was found in the WREG variety and the lowest in WSBL.

The weight of the lignified shoots ranged from 0.67 to $0.93 \mathrm{~kg} \cdot \mathrm{shrub}{ }^{-1}$, i.e., from 3.36 to $4.65 \mathrm{t} \cdot \mathrm{ha}^{-1}$ per unit area. The WRON grapevines produced significantly higher shoot weight than the other grapevine varieties evaluated. In the study by Rosúa and Pasadas [19] conducted in Spain, fresh viticulture waste production was found to be about $0.5 \mathrm{~kg}$ per shrub, or $934 \mathrm{~kg}$ per hectare. Corona and Nicoletti [31] report values of $2240 \mathrm{~kg}$ per hectare. 
Manzone et al. [17], studying residues in Italian vineyards, determined values between 0.45 to $1.34 \mathrm{~kg}$ per shrub, i.e., 1850 to $5360 \mathrm{~kg}$ per hectare.

The analysis showed a significant effect of variety on the diameter of lignified shoots. It was shown that the shoots of WSBL variety were significantly thicker than WSOL and WREG. Table 3 summarizes the determined physicochemical properties for the tested grapevine shoots.

Table 3. Technical and elemental analysis for waste shoots of selected grape varieties.

\begin{tabular}{ccccccc}
\hline Parameter & Unit & WSOL & WRON & WSBL & WREG & $p$-Value \\
\hline LHV & & $15.97^{\mathrm{bc}}$ & $15.88^{\mathrm{c}}$ & $16.04^{\mathrm{b}}$ & $16.19^{\mathrm{a}}$ & \\
$\pm \mathrm{S}_{\mathrm{d}}$ & $\mathrm{MJ} \cdot \mathrm{kg}^{-1}$ & $\pm 0.05^{\mathrm{c}}$ & \pm 0.03 & \pm 0.05 & \pm 0.03 & $<0.001^{*}$ \\
$\mathrm{HHV}$ & & $17.36^{\mathrm{bc}}$ & $17.18^{\mathrm{c}}$ & $17.52^{\mathrm{b}}$ & $17.60^{\mathrm{a}}$ & $<0.001^{*}$ \\
$\pm \mathrm{S}_{\mathrm{d}}$ & $\mathrm{MJ} \cdot \mathrm{kg}^{-1}$ & \pm 0.05 & \pm 0.04 & \pm 0.05 & \pm 0.03 & \\
$\mathrm{M}$ & & $7.04^{\mathrm{c}}$ & $6.60^{\mathrm{d}}$ & $7.43^{\mathrm{a}}$ & $7.05^{\mathrm{b}}$ & $<0.001^{*}$ \\
$\pm \mathrm{S}_{\mathrm{d}}$ & $\%$ & \pm 0.01 & \pm 0.01 & \pm 0.01 & \pm 0.01 & \\
$\mathrm{~V}$ & & $70.92^{\mathrm{ab}}$ & $71.01^{\mathrm{a}}$ & $70.52^{\mathrm{bc}}$ & $70.41^{\mathrm{c}}$ & \multirow{2}{*}{$0.006^{*}$} \\
$\pm \mathrm{S}_{\mathrm{d}}$ & $\%$ & \pm 0.28 & \pm 0.19 & \pm 0.05 & \pm 0.04 & \\
$\mathrm{~A}$ & & $4.07^{\mathrm{a}}$ & $4.21^{\mathrm{a}}$ & $3.62^{\mathrm{b}}$ & $3.68^{\mathrm{b}}$ & $<0.001^{*}$ \\
$\pm \mathrm{S}_{\mathrm{d}}$ & $\%$ & \pm 0.04 & \pm 0.07 & \pm 0.05 & \pm 0.09 & \\
$\mathrm{FC}$ & & $17.98^{\mathrm{c}}$ & $18.20^{\mathrm{bc}}$ & $18.43^{\mathrm{b}}$ & $18.86^{\mathrm{a}}$ & $<0.001^{*}$ \\
$\pm \mathrm{S}_{\mathrm{d}}$ & $\%$ & \pm 0.09 & \pm 0.09 & \pm 0.10 & \pm 0.10 & \\
$\mathrm{C}$ & & $48.69^{\mathrm{b}}$ & $48.22^{\mathrm{c}}$ & $48.90^{\mathrm{b}}$ & $49.19^{\mathrm{a}}$ & $<0.001^{*}$ \\
$\pm \mathrm{S}_{\mathrm{d}}$ & $\%$ & \pm 0.09 & \pm 0.03 & \pm 0.12 & \pm 0.13 & \\
$\mathrm{H}$ & & 5.56 & 5.97 & 5.99 & 5.95 & 0.161 \\
$\pm \mathrm{S}_{\mathrm{d}}$ & $\%$ & \pm 0.48 & \pm 0.00 & \pm 0.00 & \pm 0.02 & \\
$\mathrm{~N}$ & & 0.50 & 0.51 & 0.51 & 0.50 & 0.976 \\
$\pm \mathrm{S}_{\mathrm{d}}$ & $\%$ & \pm 0.02 & \pm 0.03 & \pm 0.03 & \pm 0.03 & \\
$\mathrm{~S}$ & & $0.06^{\mathrm{b}}$ & $0.07^{\mathrm{ab}}$ & $0.07^{\mathrm{a}}$ & $0.08^{\mathrm{ab}}$ & $0.013^{*}$ \\
$\pm \mathrm{S}_{\mathrm{d}}$ & $\%$ & \pm 0.01 & \pm 0.01 & \pm 0.01 & \pm 0.01 & \\
$\mathrm{O}$ & & 41.11 & 41.02 & 40.91 & 40.59 & 0.242 \\
$\pm \mathrm{S}_{\mathrm{d}}$ & $\%$ & \pm 0.53 & \pm 0.14 & \pm 0.17 & \pm 0.18 & \\
$\mathrm{H} / \mathrm{C}$ & & 1.37 & 1.49 & 1.47 & 1.45 & 0.146 \\
$\pm \mathrm{S}_{\mathrm{d}}$ & & \pm 0.12 & \pm 0.00 & \pm 0.00 & \pm 0.01 & \\
$\mathrm{~N} / \mathrm{C}$ & & 0.01 & 0.01 & 0.01 & 0.01 & 0.987 \\
$\pm \mathrm{S}_{\mathrm{d}}$ & & \pm 0.00 & \pm 0.00 & \pm 0.00 & \pm 0.00 & \\
$\mathrm{O} / \mathrm{C}$ & & $0.63^{\mathrm{ab}}$ & $0.64^{\mathrm{a}}$ & $0.63^{\mathrm{ab}}$ & $0.62^{\mathrm{b}}$ & \multirow{2}{*}{} \\
$\pm \mathrm{S}_{\mathrm{d}}$ & & \pm 0.01 & \pm 0.00 & \pm 0.00 & \pm 0.00 & \\
\hline
\end{tabular}

* Significant difference, $\mathrm{S}_{\mathrm{d}}$-standard deviation, $\mathrm{a}, \mathrm{b}, \mathrm{c}, \mathrm{ab}$, bc -means with the same letter in row show no significant difference at $\alpha=0.05$, LHV-lower heating value, HHV-higher heating value, $\mathrm{M}-\mathrm{moisture}$, $\mathrm{V}$-volatile matter, A-ash, FC-fixed carbon, $\mathrm{H}$-hydrogen, $\mathrm{C}$-carbon, S—sulfur, $\mathrm{N}$-nitrogen, $\mathrm{O}-\mathrm{oxygen}$.

The conducted research showed that the analyzed grapevine shoots are characterized by different energy values. The highest calorific value was found for WREG, while the lowest was found for WRON; the difference was ca. $2 \%$. The analysis of the volatile matter content showed the highest content in WRON and the lowest (lower by about $1 \%$ ) in WREG. The highest ash content was recorded for WRON and the lowest was recorded for WSBL where the difference was about $14 \%$. For FC, the highest value was recorded for WREG (18.86\%) and was about 5\% higher than the lowest value shown for WSOL (17.98\%). The elemental analysis of the studied raw materials did not show any clear differences between the materials. The determination of the carbon content results showed the highest concentration of this element for WREG $(49.19 \%)$ and the lowest for WRON $(48.22 \%)$; the difference was only less than $1 \%$. The evaluation of the hydrogen content in the analyzed grapevine shoots showed that the highest value was in WSBL and the lowest in WSOL, and the difference between the raw materials did not exceed $0.5 \%$. The analysis of the nitrogen content showed no significant differences between the grapevine varieties, and the content ranged between 0.50 and $0.51 \%$, depending on the shoots. When evaluating the content of sulfur in the individual raw materials, the highest concentration was found in 
WREG shoots $(0.08 \%)$ and the lowest WSOL (0.02\%). Keeping the above in mind, it can be concluded that the content of this element was at a low level. The oxygen content was at an average level of $40.91 \%$; the highest was recorded for WSOL (41.11\%) and the lowest was for WREG (40.59\%). Thus, the difference did not exceed $1 \%$ between the determined maximum and minimum.

The amount of energy obtained from biomass conversion is primarily related to the degree of both carbon and hydrogen content of the solid biofuel, according to the stoichiometry of the process $[32,37,38]$. The content of oxygen in the biomass also determines the amount of calorific value obtained, as it is the basis of the oxidation process. In addition, the higher the oxygen content of biomass, the higher the degree of reactivity, which results in better fuel ignition [39]. The combustion of organic matter (biomass) results in the oxidation of hydrogen and carbon contained in the fuel and this reaction, due to its exothermic course, affects the value of energy obtained.

Figure 1 shows the Van Krevelen plot for all the tested grapevine shoots. An analysis of the data from the figure allows the conclusion that the raw materials studied are in the typical range for biomass [40].

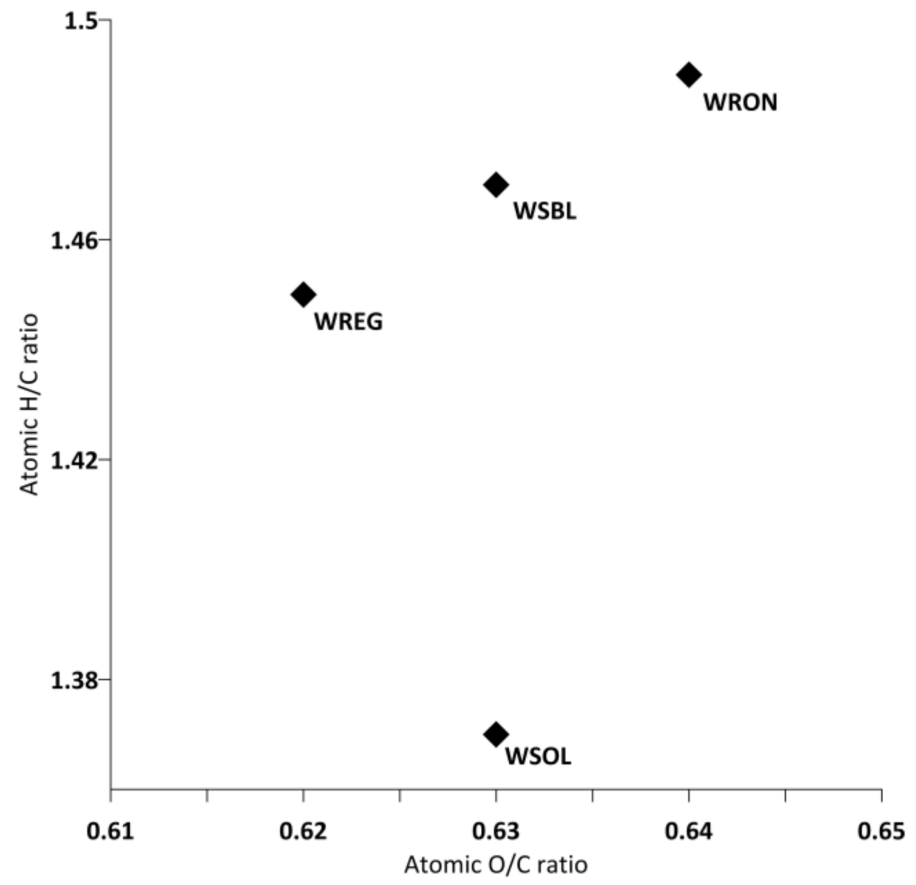

Figure 1. Molar ratio of hydrogen and oxygen (Van Krevelen Diagram): WSBL—Seyval Blanc, WSOL-Solaris, WREG-Regent and WRON-Rondo.

Biomass samples with low $\mathrm{O} / \mathrm{C}$ and $\mathrm{H} / \mathrm{C}$ ratios have better fuel properties due to the deoxygenation, decarboxylation, dehydration or denaturation of biomass [41]. Hence, the magnitude of the $\mathrm{H} / \mathrm{C}$ and $\mathrm{O} / \mathrm{C}$ ratios affects the magnitude of the energy properties of the raw material. Therefore, as the ratios increase, the calorific value decrease [32]. The analysis of the results in Figure 1 indicates that for the analyzed raw materials, the H/C (1.37-1.49) and O/C (0.62-0.64) ratios are within the range provided for biomass [40,42].

The results obtained are consistent with studies available in previous research for grapevine shoots from other grapevine varieties [43,44]. The varieties studied have slightly different characteristics. It should be noted that all of the studied varieties have a lower calorific value than Cabernet, Merlot, Prosecco or Verduzzo [13], and WREG has a similar value to Chardonnay [43] (Table 4). When comparing HHV results with values for other biomass types, similar values were noted for cereal straws (wheat, barley, rye), cereal grains [14], or olive, fig and almond trees [45]. On the other hand, when comparing the ash 
content, the grapevine varieties studied demonstrated ash contents that were below the average indicated by Fernández-Puratich et al. [43], but similar to the ash contents obtained for peach, plum, hazelnut or olive [45].

Table 4. Comparison of LHV and HHV of vineyard pruning residues.

\begin{tabular}{|c|c|c|}
\hline Material & LHV (MJ·kg $\left.{ }^{-1}\right)$ & HHV (MJ $\left.\cdot \mathrm{kg}^{-1}\right)$ \\
\hline Sauvignon blanc [43] & 17.3 & 18.7 \\
\hline Pinot $[43]$ & 15.1 & 16.5 \\
\hline Cabernet sauvignon [43] & 16.2 & 17.6 \\
\hline Chardonnay [43] & 16.2 & 17.6 \\
\hline Carmenere [43] & 17.3 & 18.7 \\
\hline Merlot [13] & - & 17.8 \\
\hline Prosecco [13] & - & 18.5 \\
\hline Verduzzo [13] & - & 18.9 \\
\hline
\end{tabular}

The performed statistical analysis proved that for the analyzed variables LHV, HHV, $\mathrm{M}, \mathrm{FC}, \mathrm{A}$ and $\mathrm{O}$, significant differences were shown between all the grapevine varieties. It was shown that the highest values of the analyzed variables (LHV, HHV, FC, C, S) are in WREG shoots. For variables $\mathrm{V}$ and $\mathrm{A}$, significant differences were also found between the analyzed varieties and, in their case, the highest values were found in WRON. In the other variables in Table 3, no significant differences were shown between the grapevine varieties. The dendrogram presented in Figure 2 makes it possible to determine the similarities between the effects of the energy parameters on the four analyzed grapevine varieties. Based on the obtained results, clear three clusters were identified, which allow unambiguous interpretation of the results. The multivariate analysis performed showed that the clusters grouped with respect to the analyzed energy parameters. Cluster one represents all four grape varieties, in the carbon content $(C)$ parameter considered. In this cluster, similarity with respect to carbon content was found between WSOL and WSBL, followed by WREG, while WRON was the most diverse. Cluster three presents similar characteristics to cluster one and, in this case, the cluster grouped with respect to HHV. Similarities between grape varieties occurred between WSOL, WSBL and WRON, while the outlier variety was WREG. The largest cluster, i.e., the second cluster, represents the grouping of all the grapevine varieties with respect to the molar coefficients $\mathrm{H} / \mathrm{C}, \mathrm{O} / \mathrm{C}$, $\mathrm{N} / \mathrm{C}$ and sulfur content (S). Within each group of parameters, similarity was found between all the considered grapevine varieties.

The technical and elemental analysis of waste in the form of one-year shoots of selected grapevine varieties showed that the energy value largely depends on the concentration of carbon in a given raw material. Due to the similar carbon content in the studied materials, each material can be used as solid biofuel, because it is characterized by good energy parameters. In comparison with other types of biomass, the determined LHV is at a similar level and it can be concluded that WSBL and WREG are characterized by aboveaverage levels of LHV. A further noteworthy finding is the low ash content, which also indicates good fuel parameters. The low content of nitrogen and sulfur can contribute to low-emission conversion processes, which makes it possible to consider the raw material as a pro-ecological fuel raw material.

Table 5 shows the emission indexes estimated using the index method.

The performed evaluation of the emission indices allows us to show the degree of environmental impact of the solid biofuel converted in the combustion process. The data analysis made it possible to note that the material with the highest $\mathrm{CO}$ emission index is WREG $\left(60.60 \mathrm{~kg} \cdot \mathrm{Mg}^{-1}\right)$, while the material with the lowest impact is WRON $\left(59.40 \mathrm{~kg} \cdot \mathrm{Mg}^{-1}\right)$. The difference between the extreme values is about $2 \%$. In terms of $\mathrm{CO}_{2}$ emission assessment, it was noted that the highest emission is characteristic for WREG $\left(1484.06 \mathrm{~kg} \cdot \mathrm{Mg}^{-1}\right)$ and the lowest for WRON $\left(1454.65 \mathrm{~kg} \cdot \mathrm{Mg}^{-1}\right)$ and this value is $2 \%$ lower. In terms of nitrogen oxide emissions, WRON has the highest impact $\left(1.81 \mathrm{~kg} \cdot \mathrm{Mg}^{-1}\right)$, 
followed by WSBL, while the lowest emission factors ( $2 \%$ lower than WRON) in this range were noted for WSOL and WREG $\left(1.78 \mathrm{~kg} \cdot \mathrm{Mg}^{-1}\right)$. The estimated $\mathrm{SO}_{2}$ emission rates are similar between the grapevine varieties. The highest emission index was recorded for WSBL $\left(0.16 \mathrm{~kg} \cdot \mathrm{Mg}^{-1}\right)$ and the lowest $\left(0.12 \mathrm{~kg} \cdot \mathrm{Mg}^{-1}\right)$ for WSOL, where the difference was $25 \%$. The dust emission index, related to the ash content of the individual raw materials, is the highest for WRON $\left(5.31 \mathrm{~kg} \cdot \mathrm{Mg}^{-1}\right)$ and the lowest $(14 \%$ lower $)$ for WSBL $\left(4.57 \mathrm{~kg} \cdot \mathrm{Mg}^{-1}\right)$.

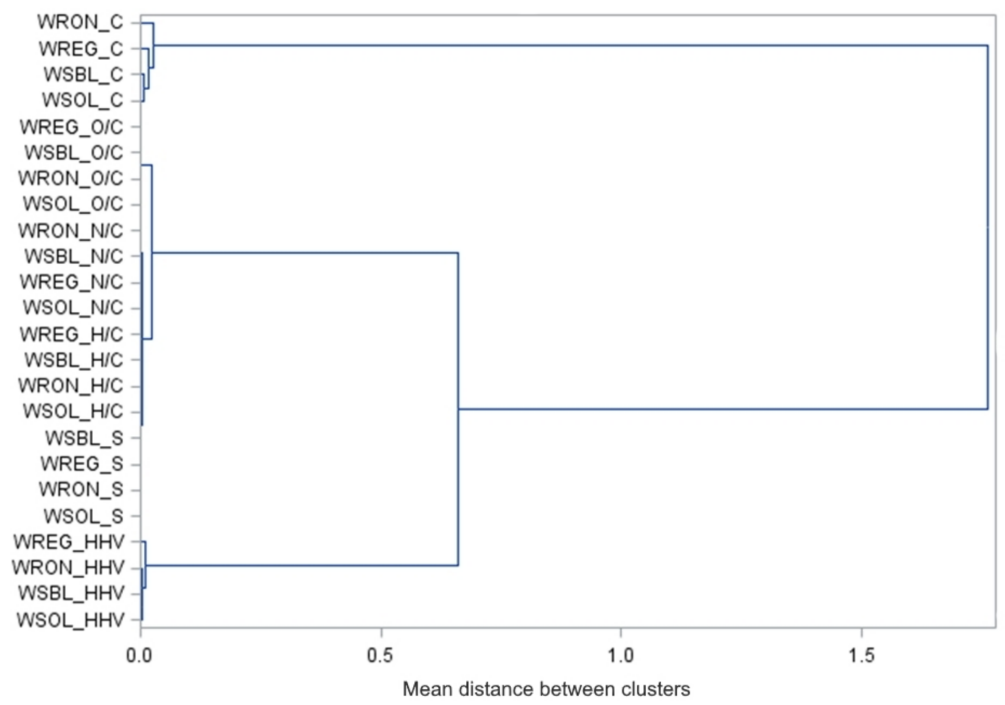

Figure 2. Comparison of analyzed waste shoots of selected grapevine varieties in relation to energy parameters: WSBL-Seyval Blanc, WSOL-Solaris, WREG—Regent, WRON-Rondo, HHV—higher heating value, $\mathrm{O}$ - oxygen, $\mathrm{C}$ - carbon, $\mathrm{S}$ - sulfur, $\mathrm{H}$ - -hydrogen and $\mathrm{N}$-nitrogen.

Table 5. Emission indexes for waste shoots of selected grapevine varieties.

\begin{tabular}{ccccccc}
\hline Parameter & Unit & WSOL & WRON & WSBL & WREG & $p$-Value \\
\hline $\mathrm{CO}$ & & $59.98^{\mathrm{b}}$ & $59.40^{\mathrm{c}}$ & $60.25^{\mathrm{b}}$ & $60.60^{\mathrm{a}}$ & \\
$\pm \mathrm{S}_{\mathrm{d}}$ & $\mathrm{kg} \cdot \mathrm{Mg}^{-1}$ & $\pm 0.15^{\mathrm{b}}$ & \pm 0.04 & $\pm 0.14^{\mathrm{c}}$ & \pm 0.11 & $<0.0001^{*}$ \\
$\mathrm{CO}_{2}$ & & $1468.87^{\mathrm{b}}$ & $1454.65^{\mathrm{c}}$ & $1475.35^{\mathrm{b}}$ & $1484.06^{\mathrm{a}}$ & \\
$\pm \mathrm{S}_{\mathrm{d}}$ & $\mathrm{kg} \cdot \mathrm{Mg}^{-1}$ & $\pm 3.87^{2}$ & \pm 0.99 & \pm 3.51 & \pm 2.62 & $<0.0001^{*}$ \\
$\mathrm{NO}_{\mathrm{x}}$ & & 1.78 & 1.81 & 1.80 & 1.78 & \\
$\pm \mathrm{S}_{\mathrm{x}}$ & $\mathrm{kg} \cdot \mathrm{Mg}^{-1}$ & \pm 0.11 & \pm 0.11 & \pm 0.12 & \pm 0.07 & 0.9763 \\
$\mathrm{SO}_{2}$ & & $0.12^{\mathrm{b}}$ & $0.14^{\mathrm{ab}}$ & $0.16^{\mathrm{a}}$ & $0.14^{\mathrm{ab}}$ & \\
$\pm \mathrm{S}_{\mathrm{d}}$ & $\mathrm{kg} \cdot \mathrm{Mg}^{-1}$ & \pm 0.01 & \pm 0.01 & \pm 0.01 & \pm 0.01 & $0.0129^{*}$ \\
$\mathrm{Dust}$ & & $5.14^{\mathrm{a}}$ & $5.31^{\mathrm{a}}$ & $4.57^{\mathrm{b}}$ & $4.65^{\mathrm{b}}$ & \\
$\pm \mathrm{S}_{\mathrm{d}}$ & $\mathrm{kg} \cdot \mathrm{Mg}^{-1}$ & \pm 0.11 & \pm 0.09 & \pm 0.06 & \pm 0.05 & $<0.0001^{*}$ \\
\hline
\end{tabular}

* Significant difference, $S_{d}$-standard deviation, a, b, c, ab - means with the same letter in row show no significant difference at $\alpha=0.05$.

The analysis of the emission factors showed that the analyzed biomass is characterized by higher emission rates relative to mint [46], tree leaves [47], rice straw [48], similar to eucalyptus globulus wood [49] and larch needles [34] and lower relative to jackfruit peel and jackfruit seeds [32]. Nevertheless, in relation to hard coal [33], it is characterized by low emissions in terms of the analyzed factors, which indicates that this fuel as environmentally friendly. Comparing CO emissions for hard coal $\left(82.01 \mathrm{~kg} \cdot \mathrm{Mg}^{-1}\right)$, using grapevine shoots as fuel, it is possible to achieve a reduction of this gas by a maximum of $27 \%$, for $\mathrm{CO}_{2}$ $\left(1969 \mathrm{~kg} \cdot \mathrm{Mg}^{-1}\right)$ of $25 \%, \mathrm{NO}_{\mathrm{x}}\left(4.09 \mathrm{~kg} \cdot \mathrm{Mg}^{-1}\right)$ of $56 \%, \mathrm{SO}_{2}\left(5.2 \mathrm{~kg} \cdot \mathrm{Mg}^{-1}\right)$ of $97 \%$ and for dust $\left(23.57 \mathrm{~kg} \cdot \mathrm{Mg}^{-1}\right)$ of $80 \%$.

The statistical analysis conducted for the data in Table 5 showed significant differences between all the grapevine varieties with respect to the analyzed variables, except for $\mathrm{NO}_{\mathrm{x}}$. In the case of $\mathrm{CO}$ and $\mathrm{CO}_{2}$, the highest values of these variables were found for WREG. 
Table 6 summarizes the estimated emission indexes in energy units.

Table 6. Emission factors for waste shoots of selected grapevine varieties per unit of energy.

\begin{tabular}{|c|c|c|c|c|c|c|}
\hline Parameter & Unit & WSOL & WRON & WSBL & WREG & $p$-Value \\
\hline $\begin{array}{l}\mathrm{CO} \\
\pm \mathrm{S}_{\mathrm{d}}\end{array}$ & $\mathrm{kg} \cdot \mathrm{GJ}^{-1}$ & $\begin{array}{c}3.76 \\
\pm 0.01\end{array}$ & $\begin{array}{c}3.74 \\
\pm 0.01\end{array}$ & $\begin{array}{c}3.76 \\
\pm 0.01\end{array}$ & $\begin{array}{c}3.74 \\
\pm 0.01\end{array}$ & 0.2168 \\
\hline $\begin{array}{l}\mathrm{NO}_{\mathrm{x}} \\
\pm \mathrm{S}_{\mathrm{d}}\end{array}$ & $\mathrm{kg} \cdot \mathrm{GJ}^{-1}$ & $\begin{array}{c}0.11 \\
\pm 0.01\end{array}$ & $\begin{array}{c}0.11 \\
\pm 0.01\end{array}$ & $\begin{array}{c}0.11 \\
\pm 0.01\end{array}$ & $\begin{array}{c}0.11 \\
\pm 0.01\end{array}$ & 0.8971 \\
\hline $\begin{array}{l}\mathrm{CO}_{2} \\
\pm \mathrm{S}_{\mathrm{d}}\end{array}$ & $\mathrm{kg} \cdot \mathrm{GJ}^{-1}$ & $\begin{array}{l}91.98 \\
\pm 0.38\end{array}$ & $\begin{array}{l}91.60 \\
\pm 0.16\end{array}$ & $\begin{array}{l}91.98 \\
\pm 0.11\end{array}$ & $\begin{array}{l}91.67 \\
\pm 0.26\end{array}$ & 0.2168 \\
\hline $\begin{array}{l}\mathrm{SO}_{2} \\
\pm \mathrm{S}_{\mathrm{d}}\end{array}$ & $\mathrm{kg} \cdot \mathrm{GJ}^{-1}$ & $\begin{array}{l}0.01^{b} \\
\pm 0.01\end{array}$ & $\begin{array}{c}0.01^{\mathrm{ab}} \\
\pm 0.01\end{array}$ & $\begin{array}{c}0.01^{\mathrm{a}} \\
\pm 0.016\end{array}$ & $\begin{array}{c}0.01^{\mathrm{ab}} \\
\pm 0.01\end{array}$ & 0.0198 * \\
\hline $\begin{array}{l}\text { dust } \\
\pm \mathrm{S}_{\mathrm{d}}\end{array}$ & $\mathrm{kg} \cdot \mathrm{GJ}^{-1}$ & $\begin{array}{l}0.32^{\mathrm{a}} \\
\pm 0.01\end{array}$ & $\begin{array}{l}0.33^{\mathrm{a}} \\
\pm 0.01\end{array}$ & $\begin{array}{l}0.29 \mathrm{~b} \\
\pm 0.01\end{array}$ & $\begin{array}{l}0.29 \mathrm{~b} \\
\pm 0.01\end{array}$ & $<0.0001$ * \\
\hline
\end{tabular}

* Significant difference, $\mathrm{S}_{\mathrm{d}}$-standard deviation, $\mathrm{a}, \mathrm{b}, \mathrm{c}, \mathrm{ab}$-means with the same letter in row show no significant difference at $\alpha=0.05$.

The emission factors per energy unit indicate the relationship of environmental impact in relation to energy yield. In terms of $\mathrm{CO}$ emissions, the highest index was recorded for WSOL and WBSL, while the lowest (lower by $1 \%$ ) was recorded for WRON and WREG. When analyzing the $\mathrm{CO}_{2}$ emission factor, the highest value was recorded for the two raw materials, i.e., WSOL and WSBL $\left(91.98 \mathrm{~kg} \cdot \mathrm{GJ}^{-1}\right)$, while the lowest was recorded for WRON $\left(91.60 \mathrm{~kg} \cdot \mathrm{GJ}{ }^{-1}\right)$. The emission factors of $\mathrm{NO}_{\mathrm{x}}\left(0.11 \mathrm{~kg} \cdot \mathrm{GJ}{ }^{-1}\right)$ and $\mathrm{SO}_{2}\left(0.01 \mathrm{~kg} \cdot \mathrm{GJ}{ }^{-1}\right)$ per unit of energy for all the raw materials are identical. In terms of dust emission factors, the highest values were shown by WRON $\left(0.33 \mathrm{~kg} \cdot G \mathrm{GJ}{ }^{-1}\right)$, while the lowest values were shown by WSBL and WREG $\left(0.29 \mathrm{~kg} \cdot \mathrm{GJ}^{-1}\right)$. The statistical analysis in Table 6 only shows differences between the grapevine varieties for dust.

Based on the stoichiometric equations, the theoretical air demand and the amount and composition of dry exhaust were calculated (Table 7). The calculated value of theoretical air demand for each of the tested plants was comparable.

Table 7. The balance of the amount of substances in the process of burning vine shoots.

\begin{tabular}{ccccccc}
\hline Nazwa & Unit & WSOL & WRON & WSBL & WREG & $p$-Value \\
\hline $\mathrm{V}_{\mathrm{OO} 2}$ & \multirow{2}{*}{$\mathrm{Nm}^{3} \cdot \mathrm{kg}^{-1}$} & 0.93 & 0.95 & 0.95 & 0.95 & \\
$\pm \mathrm{S}_{\mathrm{d}}$ & & \pm 0.01 & \pm 0.01 & \pm 0.01 & \pm 0.03 & 0.1461 \\
$\mathrm{~V}_{\mathrm{oa}}$ & $\mathrm{Nm}^{3} \cdot \mathrm{kg}^{-1}$ & 4.44 & 4.53 & 4.53 & 4.52 & \\
$\pm \mathrm{S}_{\mathrm{d}}$ & & \pm 0.01 & \pm 0.01 & \pm 0.01 & \pm 0.15 & 0.1035 \\
$\mathrm{~V}_{\mathrm{CO} 2}$ & $\mathrm{Nm}^{3} \cdot \mathrm{kg}^{-1}$ & $0.91^{\mathrm{b}}$ & $0.91^{\mathrm{c}}$ & $0.90^{\mathrm{b}}$ & $0.90^{\mathrm{a}}$ & \\
$\pm \mathrm{S}_{\mathrm{d}}$ & & \pm 0.01 & \pm 0.01 & \pm 0.01 & \pm 0.01 & $<0.0001^{*}$ \\
$\mathrm{~V}_{\mathrm{SO} 2}$ & $\mathrm{Nm}^{3} \cdot \mathrm{kg}^{-1}$ & $0.00^{\mathrm{b}}$ & $0.00 \mathrm{ab}$ & $0.00^{\mathrm{a}}$ & $0.00^{\mathrm{ab}}$ & \\
$\pm \mathrm{S}_{\mathrm{d}}$ & & \pm 0.01 & \pm 0.01 & \pm 0.01 & \pm 0.01 & $0.0129 *$ \\
$\mathrm{~V}_{\mathrm{H} 2 \mathrm{O}}$ & $\mathrm{Nm}^{3} \cdot \mathrm{kg}^{-1}$ & 1.43 & 1.47 & 1.48 & 1.48 & \\
$\pm \mathrm{S}_{\mathrm{d}}$ & & \pm 0.01 & \pm 0.01 & \pm 0.01 & \pm 0.07 & 0.1036 \\
$\mathrm{~V}_{\mathrm{N} 2}$ & $\mathrm{Nm}^{3} \cdot \mathrm{kg}^{-1}$ & 3.91 & 3.99 & 3.98 & 3.98 & \\
$\pm \mathrm{S}_{\mathrm{d}}$ & & \pm 0.02 & \pm 0.02 & \pm 0.03 & \pm 0.12 & 0.1315 \\
$\mathrm{~V}_{\mathrm{gu}}$ & $\mathrm{Nm}^{3} \cdot \mathrm{kg}^{-1}$ & 4.82 & 4.90 & 4.89 & 4.88 & \\
$\pm \mathrm{S}_{\mathrm{d}}$ & & \pm 0.02 & \pm 0.02 & \pm 0.03 & \pm 0.02 & 0.1034 \\
$\mathrm{~V}_{\mathrm{ga}}$ & $\mathrm{Nm}^{3} \cdot \mathrm{kg}^{-1}$ & 6.25 & 6.37 & 6.37 & 6.36 & \\
$\pm \mathrm{S}_{\mathrm{d}}$ & & \pm 0.02 & \pm 0.02 & \pm 0.03 & \pm 0.02 & 0.1173
\end{tabular}

* Significant difference, $\mathrm{S}_{\mathrm{d}}$-standard deviation, $\mathrm{a}, \mathrm{b}, \mathrm{c}$, ab-means with the same letter in row show no significant difference at $\alpha=0.05, \mathrm{~V}_{\mathrm{oO} 2}$ - the theoretical oxygen demand, $\mathrm{V}_{\mathrm{oa}}$ - the stoichiometric volume of dry air required to burn $1 \mathrm{~kg}$ of biomass, $\mathrm{V}_{\mathrm{CO} 2}$ - the carbon dioxide content of the combustion products, $\mathrm{V}_{\mathrm{SO} 2}$ - the content of sulfur dioxide in the exhaust gas, $\mathrm{V}_{\mathrm{H} 2 \mathrm{O}}$ - the water vapor content of the exhaust gas, $\mathrm{V}_{\mathrm{N} 2}$ - the theoretical nitrogen content in the exhaust gas, $\mathrm{V}_{\mathrm{gu}}$ - the total stoichiometric volume of dry exhaust gas, $\mathrm{V}_{\mathrm{ga}}$ - the total volume of exhaust gases. 
Analyzing the theoretical oxygen demand in the exhaust gas, no significant differences were observed in the values calculated on the basis of stoichiometric equations for all the studied grapevine shoots. The highest demand was found for the three raw materials, i.e., WRON, WSBL and WREG $\left(0.95 \mathrm{Nm}^{3} \cdot \mathrm{kg}^{-1}\right)$, while the lowest was found for WSOL $\left(0.93 \mathrm{Nm}^{3} \cdot \mathrm{kg}^{-1}\right)$. The differences were less than $2 \%$. Analyzing the calculated exhaust gas composition based on stoichiometric equations, it can be concluded that the higher the nitrogen content in the exhaust gas, the lower the proportion of carbon dioxide. The highest $\mathrm{CO}_{2}$ content was found in the exhaust gases from WSOL and WRON $\left(0.91 \mathrm{Nm}^{3} \cdot \mathrm{kg}^{-1}\right)$, while the lowest was found in WSBL and WREG $\left(0.90 \mathrm{Nm}^{3} \cdot \mathrm{kg}^{-1}\right)$. The $\mathrm{SO}_{2}$ content in the exhaust gas affects the corrosiveness of the equipment as well as the environmental impact. Hence, it should be noted that the $\mathrm{SO}_{2}$ content levels based on stoichiometric equations were very low. The nitrogen content in the exhaust gas ranged from $3.91-3.99 \mathrm{Nm}^{3} \cdot \mathrm{kg}^{-1}$ and extreme values were recorded for WSOL (minimum) and WRON (maximum). The total stoichiometric volume of dry exhaust gases for the tested grapevine shoots was at similar levels; the highest was recorded for WRON $\left(4.90 \mathrm{Nm}^{3} \cdot \mathrm{kg}^{-1}\right)$ and was $1.5 \%$ higher than that estimated for WSOL $\left(4.82 \mathrm{Nm}^{3} \cdot \mathrm{kg}^{-1}\right)$, which was the lowest. The total exhaust gas volume estimated from the stoichiometric equations ranged, depending on the raw material type, from $6.25 \mathrm{Nm}^{3} \cdot \mathrm{kg}^{-1}$ (WSOL) to $6.37 \mathrm{Nm}^{3} \cdot \mathrm{kg}^{-1}$ (WRON and WSBL). The total exhaust volume, calculated from the stoichiometric equations for each of the plants tested, was comparable; the differences were about $2 \%$. Considering the theoretical cubical quantity of dry combination gas, there was a notable similarity in the obtained data for the analyzed grapevine shoots $\left(4.82-4.90 \mathrm{Nm}^{3} \cdot \mathrm{kg}^{-1}\right)$ in relation to poplar bark [50] and Jatropha press cake [51]. The theoretical oxygen demand obtained for the studied raw materials $\left(0.93-0.95 \mathrm{Nm}^{3} \cdot \mathrm{kg}^{-1}\right)$ is at a similar level in relation to poplar pellets and forest wood chips and higher on average by $2 \%$ than oat grains, knotweed pellets and alfalfa pellets [52]. Analyzing the theoretical concentration of carbon dioxide in dry flue gases showed for the studied grapevine varieties an average of $5 \%$ lower $\mathrm{CO}_{2}$ content in relation, among others, to meadow hay, Timothy grass [53], poplar pellets, forest wood chips, or oats grains [52]. The nitrogen content was at similar levels to other biomass raw materials [51-53].

On the basis of the multivariate analysis, the effect of waste shoots of four grapevine varieties on the amount of combustion products obtained was demonstrated. The analysis of the data in Figure 3 shows a division into two clusters, which is based on the parameters of sulfur content $\left(\mathrm{V}_{\mathrm{SO} 2}\right)$ and carbon dioxide content $\left(\mathrm{V}_{\mathrm{CO} 2}\right)$ in the combustion products. Cluster one clusters the $\mathrm{V}_{\mathrm{SO} 2}$ parameter, showing no differences between the grapevine varieties studied. Cluster two shows one cluster consisting of WSOL and WSBL varieties with respect to $\mathrm{V}_{\mathrm{CO} 2}$, indicating no significant differences for this parameter. Another variety showing similarities with WSOL and WSBL in cluster two is WREG relative to $\mathrm{V}_{\mathrm{CO} 2}$, while WRON is the most significant outlier relative to the other grapevines analyzed. 


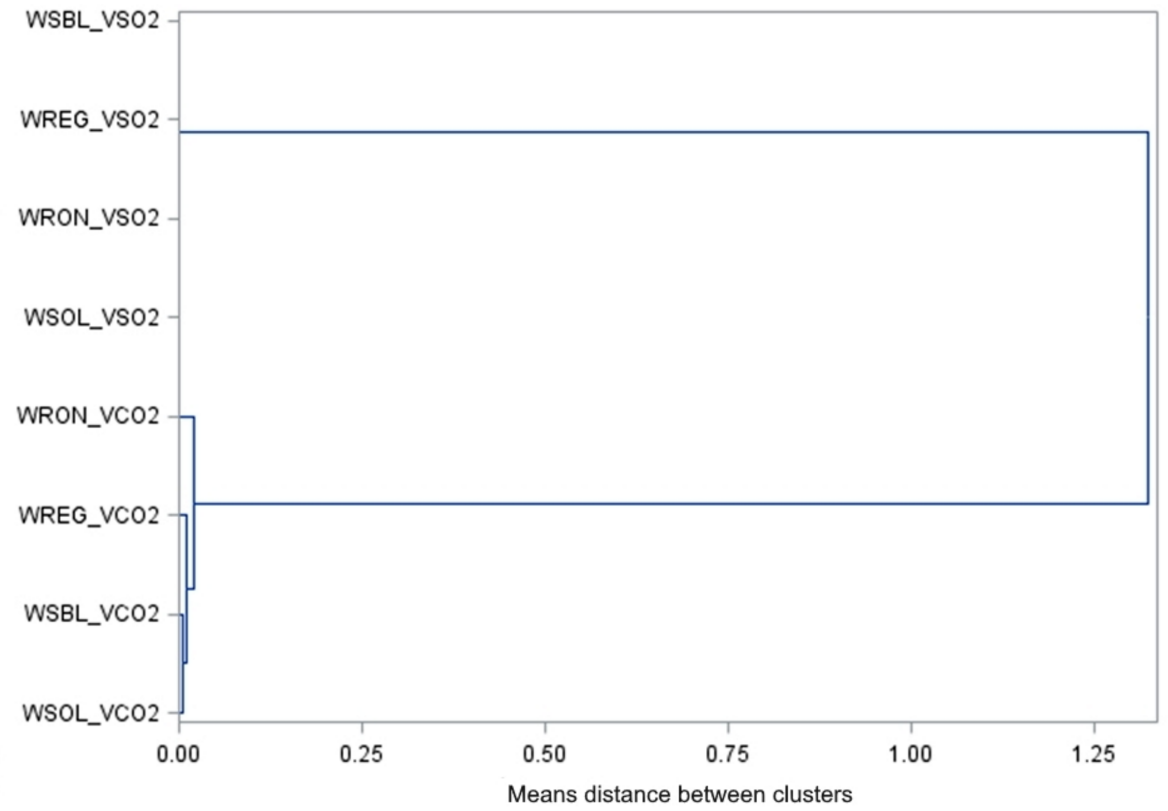

Figure 3. Comparison of analyzed waste shoots of selected grapevine varieties in relation to the balance of substances in the products of grapevine shoot combustion: WSBL-Seyval Blanc, WSOLSolaris, WREG-Regent, WRON-Rondo, $\mathrm{V}_{\mathrm{CO} 2}$ - the carbon dioxide content in the exhaust gas, $\mathrm{V}_{\mathrm{SO} 2}$ - the content of sulfur dioxide in the exhaust gas.

\section{Conclusions}

The cultivation of grapevines involves the generation of pruning waste, resulting in a large amount of raw material remaining on a given acreage, along with the necessary management involved. Due to the large quantities of shoots obtained from pruning, the grapevine cultivation system requires the indication of proper and effective management of this type of waste.

With the above in mind, an energy assessment of the shoots of selected grapevine varieties was performed. The study showed that the studied grapevine varieties are characterized by a high level of calorific value (15.88-16.19 MJ $\left.\cdot \mathrm{kg}^{-1}\right)$, as well as low ash content, which endows this type of material with potential as a solid biofuel. The performed evaluation of the emission factors showed a low degree of impact in relation to hard coal. It can be estimated that the use of the analyzed raw materials in place of hard coal could reduce $\mathrm{CO}$ emissions by $26-27 \%, \mathrm{CO}_{2}$ by $24-26 \%, \mathrm{NO}_{x}$ by $55-56 \%, \mathrm{SO}_{2}$ by $96-97 \%$ and dust by $77-80 \%$. It can be observed that, taking into account all the statistical analyses carried out, most often the waste shoots from WREG grapevine showed the highest values of the analyzed variables, which indicates its high energy usefulness.

The energy obtained from solid biofuel in the form of grape shoots can be used for purposes related to the production and operation of production farms, while reducing the use of conventional fuels. Moreover, the utilization of biowaste for energy purposes will contribute to ensuring proper cultivation hygiene and solving the problem of storing cut shoots.

Author Contributions: Conceptualization. G.M., M.K. and K.K.; methodology. G.M. and M.K.; software. K.K.; validation. G.M., K.K. and E.W.-J.; formal analysis. G.M. and K.K.; investigation. G.M., M.K. and K.K.; resources. M.K. and K.K.; data curation. G.M. and K.K.; writing-original draft preparation. G.M. and M.K.; writing-review and editing. G.M. and M.K.; visualization. G.M., E.W.-J. and K.K.; supervision. G.M.; project administration. G.M.; funding acquisition. G.M., M.K. and K.K. All authors have read and agreed to the published version of the manuscript.

Funding: Statutory activity of the University of Life Sciences in Lublin. 


\section{Institutional Review Board Statement: Not applicable.}

Informed Consent Statement: Not applicable.

Data Availability Statement: Not applicable.

Conflicts of Interest: The authors declare no conflict of interest.

\section{References}

1. Roca, P. Statistical Report on World Vitiviniculture; International Organisation of Vine and Wine Intergovernmental Organisation. OIV: Paris, France, 2019; pp. 1-23.

2. Lisek, J. Winter Hardiness of Thirty Grape Cultivar Buds (Vitis Sp.) under Conditions of Central Poland. Zesz. Probl. Postepow Nauk. Rol. 2004, 497, 405-410.

3. Lisek, J. Climatic Factors Affecting Development and Yielding of Grapevine in Central Poland. J. Fruit Ornam. Plant Res. 2008, 16, 285-293.

4. Lisek, J. Frost Damage of Buds on One-Year-Old Shoots of Wine and Table Grapevine Cultivars in Central Poland Following the Winter of 2008/2009. J. Fruit Ornam. Plant Res. 2009, 17, 149-161.

5. Dobrowolska-Iwanek, J.; Gąstol, M.; Wanat, A.; Krośniak, M.; Jancik, M.; Zagrodzki, P. Wine of Cool-Climate Areas in South Poland. S. Afr. J. Enol. Vitic. 2014, 35, 1-9. [CrossRef]

6. Kapłan, M.; Najda, A. Antioxidant Activity of Vine Fruits Depending on Their Colouring. Chemija 2014, 25, 51-55.

7. Wino/Wine. Available online: https://www.kowr.gov.pl/interwencja/wino (accessed on 6 May 2021).

8. De la Fuente Lloreda, M. Use of Hybrids in Viticulture. A Challenge for the OIV. OENO One 2018, 52, 231-234. [CrossRef]

9. Raddova, J.; Stefkova, A.; Sotolar, R.; Baranek, M. Genetic Analysis of Vitis Interspecific Hybrids Occurring in Vineyards of the Czech Republic. Pak. J. Bot. 2016, 48, 681-688.

10. Sinoquet, N. Piwi-Sorten: Die Zukunft Im Weinbau? Available online: https://academie-du-vin.ch/die-wichtigstentraubensorten-weltweit/ (accessed on 8 May 2021).

11. Caliari, V.; Burin, V.M.; Rosier, J.P.; BordignonLuiz, M.T. Aromatic Profile of Brazilian Sparkling Wines Produced with Classical and Innovative Grape Varieties. Food Res. Int. 2014, 62, 965-973. [CrossRef]

12. De Bem, B.; Brighenti, E.; Bonin, B.F.; Allembrandt, R.; Araújo, L.; Brighenti, A.F.; Bogo, A. Downy Mildew Intensity in Tolerant Grapes Varieties in Highlands of Southern Brazil. In Proceedings of the BIO Web of Conferences, Bento Goncalves, Brazil, 24-28 October 2016; Volume 7, p. 01015.

13. Spinelli, R.; Nati, C.; Pari, L.; Mescalchin, E.; Magagnotti, N. Production and Quality of Biomass Fuels from Mechanized Collection and Processing of Vineyard Pruning Residues. Appl. Energy 2012, 89, 374-379. [CrossRef]

14. Choudhury, N.D.; Saha, N.; Phukan, B.R.; Kataki, R. Characterization and Evaluation of Energy Properties of Pellets Produced from Coir Pith, Saw Dust and Ipomoea Carnea and Their Blends. Energy Sources Part A Recovery Util. Environ. Eff. 2021, 1-18. [CrossRef]

15. Garita-Cambronero, J.; Paniagua-García, A.I.; Hijosa-Valsero, M.; Díez-Antolínez, R. Biobutanol Production from Pruned Vine Shoots. Renew. Energy 2021, 177, 124-133. [CrossRef]

16. González-García, S.; Dias, A.C.; Clermidy, S.; Benoist, A.; Maurel, V.B.; Gasol, C.M.; Gabarrell, X.; Arroja, L. Comparative Environmental and Energy Profiles of Potential Bioenergy Production Chains in Southern Europe. J. Clean. Prod. 2014, 76, 42-54. [CrossRef]

17. Manzone, M.; Paravidino, E.; Bonifacino, G.; Balsari, P. Biomass Availability and Quality Produced by Vineyard Management during a Period of 15 Years. Renew. Energy 2016, 99, 465-471. [CrossRef]

18. Senila, L.; Tenu, I.; Carlescu, P.; Corduneanu, O.R.; Dumitrachi, E.P.; Kovacs, E.; Scurtu, D.A.; Cadar, O.; Becze, A.; Senila, M.; et al Sustainable Biomass Pellets Production Using Vineyard Wastes. Agriculture 2020, 10, 501. [CrossRef]

19. Rosúa, J.M.; Pasadas, M. Biomass Potential in Andalusia, from Grapevines, Olives, Fruit Trees and Poplar, for Providing Heating in Homes. Renew. Sustain. Energy Rev. 2012, 16, 4190-4195. [CrossRef]

20. Burg, P.; Mašán, V.; Zemánek, P.; Rutkowski, K. Review of Energy Potential of the Wood Biomass of Orchards and Vineyards in the Czech Republic. Res. Agric. Eng. 2017, 63, S1-S7.

21. van Dam, J.; Faaij, A.P.C.; Lewandowski, I.; Fischer, G. Biomass Production Potentials in Central and Eastern Europe under Different Scenarios. Biomass Bioenergy 2007, 31, 345-366. [CrossRef]

22. Souček, J.; Burg, P.; Kroulik, M. Dřevo z Ovocnỳch Vỳsadeb Jako Potenciální Zdroj Energie. In Proceedings of the Sborník z Mezinárodní Konference Strom a Květina-Součást Života, Pruhonice, Czech Republic, 4-5 September 2007; Volume 4, p. 9.

23. Di Blasi, C.; Tanzi, V.; Lanzetta, M. A Study on the Production of Agricultural Residues in Italy. Biomass Bioenergy 1997, 12, 321-331. [CrossRef]

24. Mendívil, M.A.; Muñoz, P.; Morales, M.P.; Juárez, M.C.; García-Escudero, E. Chemical Characterization of Pruned Vine Shoots from La Rioja (Spain) for Obtaining Solid Bio-Fuels. J. Renew. Sustain. Energy 2013, 5, 033113. [CrossRef]

25. Spinelli, R.; Lombardini, C.; Pari, L.; Sadauskiene, L. An Alternative to Field Burning of Pruning Residues in Mountain Vineyards. Ecol. Eng. 2014, 70, 212-216. [CrossRef] 
26. Scarlat, N.; Blujdea, V.; Dallemand, J.-F. Assessment of the Availability of Agricultural and Forest Residues for Bioenergy Production in Romania. Biomass Bioenergy 2011, 35, 1995-2005. [CrossRef]

27. Magagnotti, N.; Nati, C.; Spinelli, R.; Vieri, M. Technical Protocol for the Utilization of Pruning Residues from Vineyards and Olive Groves. In The Forest-Wood-Energy Chain: Results from the International Project Woodland Energy; ARSIA di Regione Toscana: Florence, Italy, 2009.

28. Keshtkar, H.; Ashbaugh, L.L. Size Distribution of Polycyclic Aromatic Hydrocarbon Particulate Emission Factors from Agricultural Burning. Atmos. Environ. 2007, 41, 2729-2739. [CrossRef]

29. Chau, J.; Sowlati, T.; Sokhansanj, S.; Preto, F.; Melin, S.; Bi, X. Economic Sensitivity of Wood Biomass Utilization for Greenhouse Heating Application. Appl. Energy 2009, 86, 616-621. [CrossRef]

30. Molcan, P.; Lu, G.; Le Bris, T.; Yan, Y.; Taupin, B.; Caillat, S. Characterisation of Biomass and Coal Co-Firing on a 3 MWth Combustion Test Facility Using Flame Imaging and Gas/Ash Sampling Techniques. Fuel 2009, 88, 2328-2334. [CrossRef]

31. Corona, G.; Nicoletti, G. Renewable Energy from the Production Residues of Vineyards and Wine: Evaluation of a Business Case. New Medit 2010, 9, 41-47.

32. Alves, J.L.F.; da Silva, J.C.G.; Mumbach, G.D.; Domenico, M.D.; da Silva Filho, V.F.; de Sena, R.F.; Machado, R.A.F.; Marangoni, C. Insights into the Bioenergy Potential of Jackfruit Wastes Considering Their Physicochemical Properties, Bioenergy Indicators, Combustion Behaviors, and Emission Characteristics. Renew. Energy 2020, 155, 1328-1338. [CrossRef]

33. Borycka, B. Commodity Study on Food and Energy Utilization of Rich-Food Waste of the Fruit and Vegetables Industry. Monography; Radom University of Technology: Radom, Poland, 2008.

34. Maj, G. Emission Factors and Energy Properties of Agro and Forest Biomass in Aspect of Sustainability of Energy Sector. Energies 2018, 11, 1516. [CrossRef]

35. Kovacs, H.; Szemmelveisz, K.; Koós, T. Theoretical and Experimental Metals Flow Calculations during Biomass Combustion. Fuel 2016, 185, 524-531. [CrossRef]

36. Paraschiv, L.S.; Serban, A.; Paraschiv, S. Calculation of Combustion Air Required for Burning Solid Fuels (Coal/Biomass/Solid Waste) and Analysis of Flue Gas Composition. Energy Rep. 2020, 6, 36-45. [CrossRef]

37. Demirbas, A. Combustion Characteristics of Different Biomass Fuels. Prog. Energy Combust. Sci. 2004, 30, 219-230. [CrossRef]

38. Maj, G. Diversification and Environmental Impact Assessment of Plant Biomass Energy Use. Pol. J. Environ. Stud. 2015, 24, 2055-2061. [CrossRef]

39. Yi, Q.; Qi, F.; Cheng, G.; Zhang, Y.; Xiao, B.; Hu, Z.; Liu, S.; Cai, H.; Xu, S. Thermogravimetric Analysis of Co-Combustion of Biomass and Biochar. J. Therm. Anal. Calorim. 2013, 112, 1475-1479. [CrossRef]

40. Burnham, A.K. Van Krevelen Diagrams. In Encyclopedia of Petroleum Geoscience; Sorkhabi, R., Ed.; Springer International Publishing: Cham, Switzerland, 2018; pp. 1-5, ISBN 978-3-319-02330-4.

41. Krysanova, K.; Krylova, A.; Zaichenko, V.; Lavrenov, V.; Khaskhachikh, V. Influence of the Parameters of the Hydrothermal Carbonization of the Biomass on the Biocoal Obtained from Peat. E3S Web Conf. 2019, 114, 07003. [CrossRef]

42. Kalita, P.; Baruah, D. Investigation of Biomass Gasifier Product Gas Composition and Its Characterization. In Coal and Biomass Gasification; Springer: Singapore, 2018; pp. 115-149, ISBN 978-981-10-7334-2.

43. Fernández-Puratich, H.; Hernández, D.; Tenreiro, C. Analysis of Energetic Performance of Vine Biomass Residues as an Alternative Fuel for Chilean Wine Industry. Renew. Energy 2015, 83, 1260-1267. [CrossRef]

44. Gañán, J.; Al-Kassir Abdulla, A.; Cuerda Correa, E.M.; Macías-García, A. Energetic Exploitation of Vine Shoot by Gasification Processes: A Preliminary Study. Fuel Processing Technol. 2006, 87, 891-897. [CrossRef]

45. Bilandzija, N. Energy Potential of Fruit Tree Pruned Biomass in Croatia. Span. J. Agric. Res. 2012, $292-298$.

46. Maj, G.; Najda, A.; Klimek, K.; Balant, S. Estimation of Energy and Emissions Properties of Waste from Various Species of Mint in the Herbal Products Industry. Energies 2020, 13, 55. [CrossRef]

47. Maj, G.; Piekut, J. Comparing Emission Factors and Physicochemical Properties of Waste-Biomass Leaves of Selected Species of Trees. Pol. J. Environ. Stud. 2018, 27, 2155-2162. [CrossRef]

48. Zhang, T.; Wooster, M.J.; Green, D.C.; Main, B. New Field-Based Agricultural Biomass Burning Trace Gas, PM2.5, and Black Carbon Emission Ratios and Factors Measured in Situ at Crop Residue Fires in Eastern China. Atmos. Environ. 2015, 121, 22-34. [CrossRef]

49. Mateos, E.; Ormaetxea, L. Sustainable Renewable Energy by Means of Using Residual Forest Biomass. Energies 2019, 12, 13. [CrossRef]

50. Malaták, J.; Gürdil, G.A.K.; Jevic, P.; Selvi, K.Ç. Biomass Heat-Emission Characteristics of Energy Plants. AMA Agric. Mech. Asia Afr. Lat. Am. 2008, 39, 9-13.

51. Brunerová, A.; Malat'ák, J.; Müller, M.; Valášek, P.; Roubík, H. Tropical Waste Biomass Potential for Solid Biofuels Production. Agron. Res. 2017, 15, 359-368.

52. Malat'ák, J.; Passian, L. Heat-Emission Analysis of Small Combustion Equipments for Biomass. Res. Agric. Eng. 2011, 57, 37-50. [CrossRef]

53. Malat'ák, J.; Bradna, J.; Velebil, J. The Dependence of COx and NOx Emission Concentrations on the Excess Air Coefficient during Combustion of Selected Agricultural Briquetted By-Products. Agron. Res. 2017, 15, 1084-1093. 